\begin{tabular}{l|c|c}
\hline ISSN: 0001-5113 & ACTA ADRIAT., & SHORT COMMUNICATION \\
AADRAY & $59(2): 213-218,2018$ & \\
\hline \hline
\end{tabular}

DOI:10.32582/aa.59.2.6.

\title{
New records of Calappa tuerkayana Pastore, 1995 (Brachyura, Calappidae) from the central Mediterranean
}

\author{
Carlo PIPITONE ${ }^{1}$, Gianni INSACCO ${ }^{2, *}$, Daniela MASSI ${ }^{3}$ and Bruno ZAVA ${ }^{4}$ \\ ${ }^{I}$ CNR-IAMC, via Giovanni da Verrazzano 17, 91014 Castellammare del Golfo, Italy \\ ${ }^{2}$ Civic Museum of Natural History, via degli Studi 9, 97013 Comiso, Italy \\ ${ }^{3}$ CNR-IAMC, via Luigi Vaccara 61, 91026 Mazara del Vallo, Italy \\ ${ }^{4}$ Wilderness Environmental Studies, via Cruillas 27, 90146 Palermo, Italy \\ *Corresponding author: g.insacco@comune.comiso.rg.it
}

\begin{abstract}
Two specimens of the uncommon calappid crab Calappa tuerkayana Pastore, 1995 are reported from the central Mediterranean. One juvenile individual was caught in a trawl net at about $105 \mathrm{~m}$ depth on a detritus bottom, and one adult male was caught in a trammel net at $50 \mathrm{~m}$ depth in a similar habitat. Details about carapace ornamentation and fresh color of the adult, which complement previous descriptions are provided. Family Calappidae includes four species in the Mediterranean Sea. C. tuerkayana has been recorded a few times from its known geographic range. These are the southernmost records to date.
\end{abstract}

Key words: Mediterranean, Strait of Sicily, Calappidae, distribution, morphology, coloration

\section{INTRODUCTION}

Family Calappidae De Haan, 1883 (Crustacea, Decapoda, Brachyura) includes nine extant genera of which Calappa is the most numerous with 41 species (NG et al., 2008). Their common name of shame-faced crabs derives from the habit of hiding their "face" behind the massive, high and flat chelipeds. The genus Calappa in the Mediterranean includes four species: $C$. granulata (L., 1758), C. pelii Herklots, 1851, C. rosea Jarocki, 1825 and C. tuerkayana Pastore, 1995. Calappa granulata is by far the most common and widely distributed in the group and has a limited commercial value in some fisheries (HOLTHUIS, 1987). Calappa pelii is a west African species recorded a few times in the Mediterranean as an alien crab (PASTORE, 1995; GALIL et al., 2002). Calappa rosea ( $=$ C. rissoana Pastore, 1995) was reported from the northern Ionian Sea (PASTORE, 1995; CAPEZZUTO et al., 2010) and the Strait of Sicily (SPANÒ et al., 2004). C. tuerkayana was described by PASTORE (1995) from specimens collected in 1988 and 1993 in the Gulf of Taranto (northern Ionian Sea) and was reported a few other times from the Mediterranean (Fig. 1): Baleares Islands in 1983 (GARCIA, 2002, initially identified as $C$. granulata), southern Adriatic Sea in 1996-2000 (uncertain year) (UNGARO et al., 2005), northern Ionian Sea in 1997-2006 (CAPEZZUTO et al., 2010) 


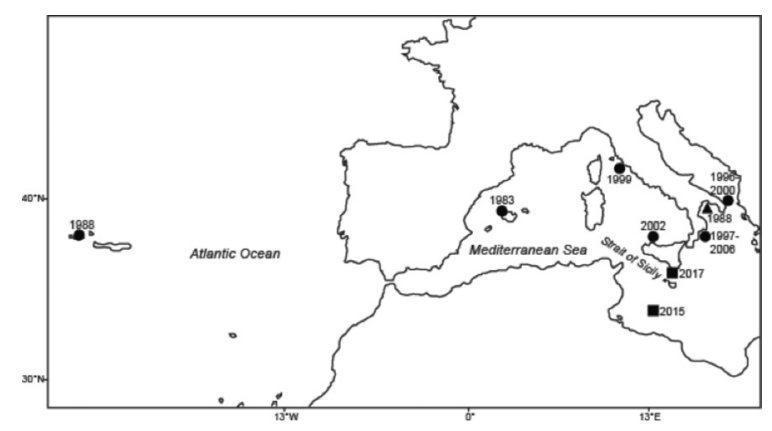

Fig. 1. Map with the locations of Calappa tuerkayana records. Dates indicate year of collection. Triangle: site of first published record. Squares: sites of present records

and Ustica Island, southern Tyrrhenian Sea in 2002 (PIPITONE \& VACCARO, 2011). One other specimen possibly belonging to $C$. tuerkayana was collected along the Tuscany coast, northern Tyrrhenian Sea in 1999 (VIGNOLI et al., 2004). D'UDEKEM D'ACOZ (2001) reported and described in detail a specimen collected in the Azores, central-northern Atlantic in 1988 and initially identified as C. granulata.

The present paper reports two records of C. tuerkayana from the northern and southern sides of the Strait of Sicily, which represent the southernmost records of the species in the Mediterranean.

\section{MATERIAL AND METHODS}

\section{Specimen no. 1}

Collection details: 12 October 2004 during a research trawl survey off western Libya (trawl haul midpoint: $34^{\circ} 20^{\prime} 60^{\prime \prime} \mathrm{N}, 1^{\circ} 02^{\prime} 20^{\prime \prime}$ E). Habitat: coarse detritus bottom at the depth of about $105 \mathrm{~m}$. The dominant accompanying invertebrate fauna present in the catch included Stylocidaris affinis, Centrostephanus longispinus, Pagurus prideaux, Adamsia palliata and Neopycnodonte cochlear. The brown seaweed Zonaria tournefortii was also present. The specimen was frozen on board, then preserved in $4 \%$ formalin and seawater solution.

The specimen is deposited in the Invertebrates collection at CNR-IAMC, Mazara del Vallo (Italy).

\section{Specimen no. 2}

Collection details: 24 March 2017 in a commercial trammel net catch obtained off Marina di Ragusa, southeastern Sicily (36 $46^{\circ} 33^{\prime \prime}$ N, $14^{\circ} 31^{\prime} 25^{\prime \prime}$ E). Habitat: coarse detritus bottom at the depth of $50 \mathrm{~m}$. The accompanying invertebrate fauna included Astrospartus mediterraneus, Derilambrus angulifrons, Pilumnus hirtellus and a sponge (cf. Ircinia sp.). The specimen was photographed while fresh, then preserved in $4 \%$ formalin and seawater solution.

The specimen is deposited at the Civic Museum of Natural History, Comiso (Italy) with code MSNC 4559.

Both crabs were identified as C. tuerkayana with the aid of the descriptions provided by PASTORE (1995) and D’UDEKEM D'ACOZ (2001).

\section{RESULTS}

\section{Specimen no. 1}

The collected individual is a juvenile with $21.2 \mathrm{~mm}$ carapace width and $18.2 \mathrm{~mm}$ carapace length. The morphology corresponds to previously published descriptions (PASTORE, 1995; D'UDEKEM D'ACOZ, 2001).

\section{Specimen no. 2}

The collected individual (Fig. 2) is an adult male with $47.5 \mathrm{~mm}$ carapace width and 39.1 $\mathrm{mm}$ carapace length. In addition to published descriptions, a few additions concerning the carapace ornamentation and the color of our specimen are provided.

Carapace margin, including rostrum and orbits, very finely granulated. First half of the antero-lateral margin with blunt, wide and very shallow teeth that resemble a slightly crenated profile. Second half bears a series of 7-8 acute teeth that gradually increase in size. Small granulations present on the entire carapace surface especially on the intestinal region, and on the outer surface of chelipeds. Ventral surface of the body and walking legs without granulations and perfectly smooth. Many intestinal granulations 


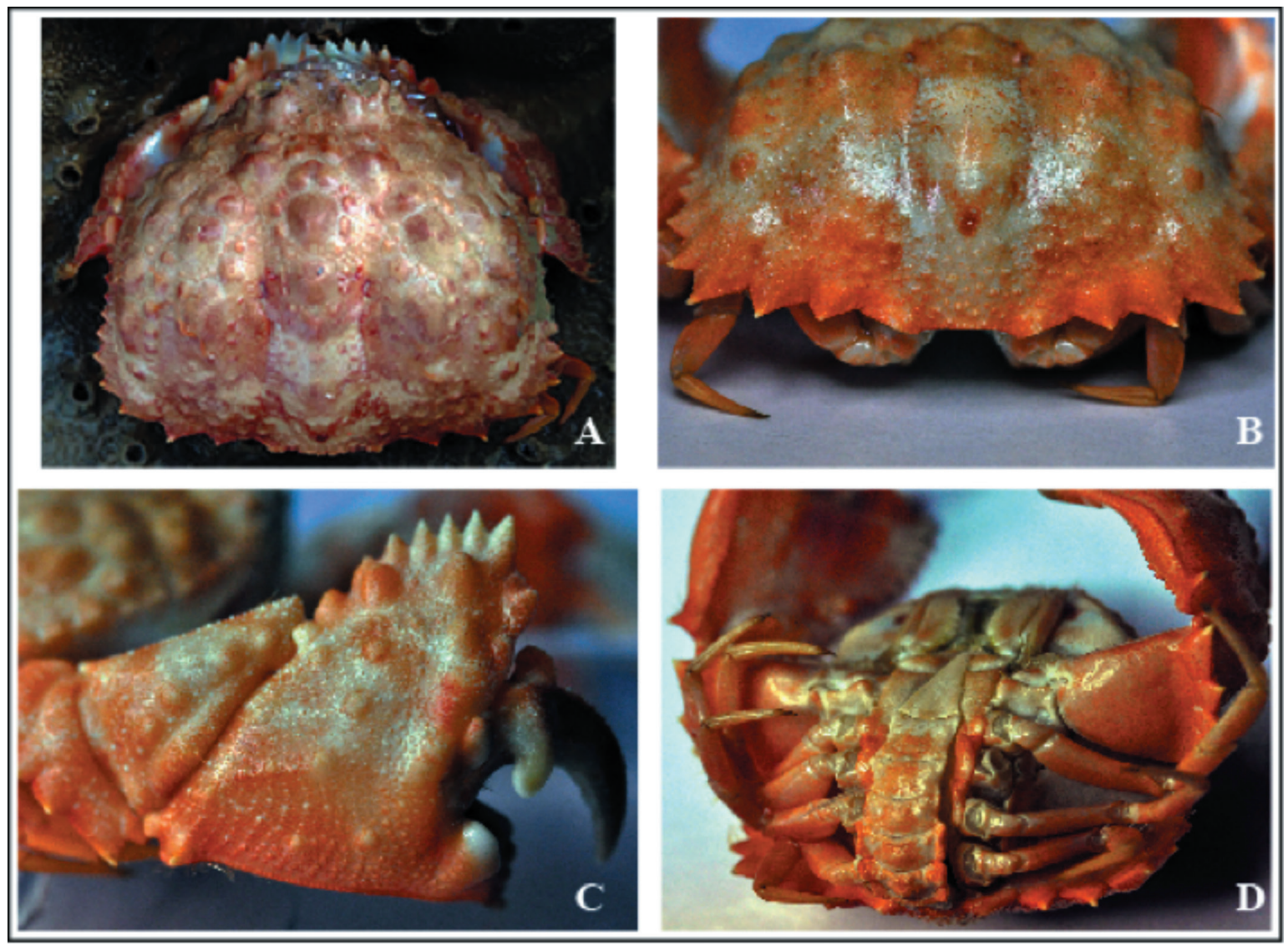

Fig. 2. Calappa tuerkayana, specimen no.2. A: dorsal view; B: posterior view of carapace; C: lateral view of right cheliped; D; ventral view. A: taken from fresh specimen; B, C and D: taken after 7 months of preservation in $4 \%$ formalin and seawater solution

are in groups of two, a few making groups of three.

General coloration of the fresh specimen rusty-brownish with paler areas in the metabranchial, cardiac and intestinal regions. Inferior surface of the carapace whitish, with the exception of the postero-lateral expansions that are the same color of the dorsal surface. Small reddish spot in the middle of the intestinal region. Larger postero-lateral spines with yellow tip. White areas on the internal surface of chelipeds corresponding to the dentate crest and proximal region of the propodus and to the central region of the carpus.

\section{DISCUSSION}

The genus Calappa found in the Strait of Sicily has included only two species so far: $C$. granulata and $C$. rosea. Both species live on soft bottom habitats, the former being clearly eurybathic (HOLTHUIS, 1987). Even though the exact habitat of both species in the Strait of Sicily records is not known, they all come from trawlable bottoms deeper than $50 \mathrm{~m}$, which in the study area are occupied to a large extent by mud or coarser sediment (GAROFALO et al., 2004). Calappa tuerkayana has been recorded throughout its known range from depths of $50 \mathrm{~m}$ or less on sand, detritus and seagrass (Posidonia oceanica), with the exception of our specimen no. 1 and of a record from about $140 \mathrm{~m}$ from trawlable grounds in the northern Ionian Sea (Francesca Capezzuto, pers. comm.). The partial habitat overlap and the very similar morphology among Mediterranean calappid crabs could have led to misidentification in the past, which could also explain the rare and scattered records of $C$. tuerkayana and $C$. rosea. In fact the specimens of $C$. tuerkayana reported by D'UDEKEM D'ACOZ 
(2001) and GARCIA (2002) were collected respectively in the same year and five years before those described by PASTORE (1995) and were initially identified as C. granulata.

Our specimens fit the previously published morphological descriptions. The availability of a fresh adult individual allowed us to add new details to the coloration of the species, helping to differentiate it from other Mediterranean calappid crabs.

As a final remark we wish to highlight the role of professional fishermen who, like in the case of specimen no. 2, often prove helpful in the knowledge of marine biodiversity.

\section{ACKNOWLEDGEMENTS}

The authors with to thank the fisherman Orazio CAUSARANO, who collected specimen no. 2. Specimen no. 1 was collected on board of F/V Sant'Anna during the GRUND trawl survey, funded by the Italian Ministry of Agricultural Policies and by the European Commission. Francesca CAPEZZUTO (University of Bari, Department of Biology) provided information about Ionian specimens. 


\section{REFERENCES}

CAPEZZUTO, F., R. CARLUCCI, P. MAIORANO, L. SION, D. BATTISTA, A. GIOVE, A. INDENNIDATE, A. TURSI \& G. D'ONGHIA. 2010. The bathyal benthopelagic fauna in the north-western Ionian Sea: structure, patterns and interactions. Chem. Ecol., 26 Suppl.: 199-217.

D'UDEKEM D'ACOZ, C. 2001. Remarks on the genera Balssia Kemp, 1922 and Acanthonyx Latreille, 1828 in the Azores, and first record of Calappa tuerkayana Pastore, 1995 (Crustacea, Decapoda) in the Atlantic Ocean. Arquipelago, 18A: 53-59.

GALIL, B., C. FROGLIA \& P. NOEL. 2002. CIESM Atlas of exotic species in the Mediterranean. Vol. 2. Crustaceans: decapods and stomatopods. CIESM. Monaco, Principality of Monaco, 192 pp.

GARCIA, L. 2002. Presencia de Calappa tuerkayana Pastore, 1995 (Decapoda: Brachyura: Calappidae) en el Mediterráneo Occidental (Presence of Calappa tuerkayana Pastore, 1995 (Decapoda: Brachyura: Calappidae) in the western Mediterranean). Boll. Soc. Hist. Nat. Balears, 45: 217-223.

GAROFAlO, G., M. GRISTINA, M. TOCCACELI, G.B. GIUSTO, P. RIZZO \& G. SINACORI. 2004. Geostatistical modelling of biocenosis distribution in the Strait of Sicily. In: T. Nishida, P.J. Kailola and C.E. Hollingworth (Editors). GIS/Spatial Analyses in Fishery and Aquatic Sciences, vol. 2. Fishery-aquatic GIS Research Group, Saitama, Japan, pp. 241-250.
HOLTHUIS, L.B. 1987. Vrais crabes. In: W. Fischer, M. Schneider and M.L. Bauchot (Editors). Fiches FAO d'identification des especes pour les besoins de la peche (Revision 1). Méditerranée et Mer Noire, zone de peche 37 . Vol. I: vegetaux et invertebres. FAO, Rome, Italy, pp. 322-367.

NG, P.K.L., D. GUINOT \& P.J.F. DAVIE. 2008. Systema Brachyurorum: Part I. An annotated checklist of extant brachyuran crabs of the world. Raffles Bull. Zool., 17: 1-186.

PASTORE, M. 1995. The genus Calappa in the Ionian Sea. Oebalia, 21: 187-196.

PIPITONE, C. \& A.M. VACCARO. 2011. Crustacea Decapoda from Ustica (southern Tyrrhenian Sea): species distribution in different habitats and sampling approach. In: D. Pessani, T. Tirelli and C. Froglia (Editor). Atti IX Colloquium Crustacea Mediterranea, Torino, Italy, 2-6 September 2008, pp. 413-434.

SPANÒ, N., G. BONO \& S. RAGONESE. 2004. On the occurrence of the shamefaced crabs Calappa granulata and C. rissoana (Decapoda: Brachyura) in the Strait of Sicily (central Mediterranean Sea). Vie Milieu, 54: 249-250.

UNGARO, N., C.A. MARANO, L. CERIOLA \& M. MARTINO. 2005. Distribution of demersal crustaceans in the southern Adriatic Sea. Acta Adriat., 46: 27-40.

VIGNOLI, V., T. CARUSO \& L. FALCIAI. 2004. Decapoda Brachyura from Monte Argentario (Mediterranean Sea, central Tyrrhenian). Crustaceana, 77: 177-186.

Received: 5 September 2018

Accepted: 30 Ocotber 2018 


\title{
Novi nalaz vrste Calappa tuerkayana Pastore, 1995 (Brachyura, Calappidae) u središnjem Sredozemlju
}

\author{
Carlo PIPITONE, Gianni INSACCO*, Daniela MASSI i Bruno ZAVA \\ *Kontakt e-pošta: g.insacco@comune.comiso.rg.it
}

\begin{abstract}
SAŽETAK
Dvije jedinke raka Calappa tuerkayana Pastore, 1995 su pronađene u središnjem Sredozemlju. Jedan primjerak mlađi je uhvaćen povlačnom mrežom na otprilike 105 metara dubine na detritusnom dnu, dok je mužjak uhvaćen u mreži na dubini od $50 \mathrm{~m}$ u sličnom staništu. Detalji opisa oklopa i svježe boje odraslih primjeraka nadopunjuju prethodne opise. Obitelj Calappidae obuhvaća četiri vrste u Sredozemnom moru. Primjerci vrste $C$. tuerkayana zabilježeni su nekoliko puta u okviru poznatog geografskog raspona.
\end{abstract}

Ključne riječi: Sredozemlje, Sicilijanski tjesnac, Calappidae, distribucija, morfologija, obojenost 